\title{
Social Trust of Indonesia's Post Conflict Society: A Case Study of Poso Regency
}

\author{
Dwia Aries Tina Pulubuhu ${ }^{1}$, Muhammad Ramli AT ${ }^{2}$, Andi Ahmad Yani ${ }^{3}$, \\ Muhammad Arsyad ${ }^{4}$, Amril Hans ${ }^{5}$, Sitti Halwatiah ${ }^{6}$ \\ \{dwiatn@yahoo.com¹, mramliat@yahoo.com², aayani@unhas.ac.id ${ }^{3}$, \\ arsyad@unhas.ac.id amrilhans@unhas.ac.id ${ }^{5}$,sitihalwatiah@gmail.com $\left.{ }^{6}\right\}$ \\ Department of Sociology, Hasanuddin University, J1.Perintis Kemerdekaan KM 10, \\ Makassar, Indonesia ${ }^{1,2}$ \\ Department of Administrative Science, Hasanuddin University, Indonesia ${ }^{3,5,6}$, \\ Department of Socio-economics of Agriculture, Hasanuddin University, Indonesia ${ }^{4}$
}

\begin{abstract}
Social trust is one of fundamental components of social capital. However, trust is generally seen as one of major social element that is weakening in a post conflict society. This study focuses on Poso society which experienced violent ethno-religious conflict which was erupted during Indonesian political transition in 1999. The study attempts to mapping Poso society's social trust after almost two decades of Malino peace agreement in 2001. The study employed mixed method and conducted survey, interview and focus group discussion to collect data. There were 450 questionnaires were distributed and 373 respondents or 83 percent were returned. The data was analyzed by descriptive statistical method with frequency and percentage to analyze trend of respondents' tendency to their degree of social trust. This research shows quite clearly that the level of trust of the population towards other parties in areas that have experienced conflict is quite low. The extent of mistrust on the other side is evident both to those of their own ethnicity or religion, as well as to those of different ethnicities and religions. Even so, there was a distribution of respondents who increased their distrust if the other parties were also different in religion and ethnicity. This shows that postconflict social recovery efforts that have so far not been fully successful in improving trust between members of the community.
\end{abstract}

Keywords: Social Trust, Post Conflict Society, Poso, Indonesia

\section{Introduction}

One important aspect related to how to care for a plural society like Indonesia is social trust. That is because plural society consists of social units, especially ethnic groups who traditionally live separately. Observing Indonesian society during the Dutch East Indies, Furnival then described this plural society as a society consisting of two or more elements that lived independently without any intermingling in one political unit [1].

Nasikun [1] himself describes the structure of Indonesian society with its two very unique characteristics. First, horizontally marked by the existence of social units based on a number of differences in ethnicity, religion, tradition and regional differences. Second, the vertical structure of society is marked by a number of differences between the upper and lower layers 
which are quite sharp [1] [2]. In the current era, vertical structures are also formed or maintained by what is commonly called the economic paradox [2]. The condition of the Indonesian economy at the macro level often gets praise which should have an effect on remembering social welfare. However, in a paradoxical condition, improving prospects and economic performance does not in itself increase social welfare [3].

So, on the one hand plural societies have the advantage of having gone through a long history of living side by side in diversity. But on the other hand, the development of such a society is also not uncommon to experience problems in strengthen relations between them.

The longstanding social conflict in Indonesia can be seen as part of the phenomenon of plural society that has not been fully able to overcome the problems between them, especially related to how to maintain harmonious relations in the diversity attached to it. The conflict can arise through a variety of triggering factors, both political and due to socio-economic problems[4]. In Indonesia, one of the peaks was when the monetary crisis in the late 1990s triggered a political crisis and a change of power[5][6]. The power of the New Order under the Suharto regime which was strong and for decades succeeded in suppressing various conflicts, suddenly collapsed and shifted to periods of government that were still weak and not yet fully consolidated[7]. This condition seems to have an effect on the weakening of the bonds that have been uniting various social units. In the end this condition allows the potential for conflicts that have been latent under authoritarian rule, to turn into open conflicts that have exploded in various places in this diverse and wide country.

Various things can be a trigger for conflict during these political transition periods[6],[8]. But one of the common threads that are seen is thin mutual trust between social groups, so that the relatively small problems that occur between them can trigger large-scale conflicts[9]. This example can be seen in various places, both in Papua, Ambon, Kalimantan, Aceh, and also in Poso. In these places, relatively small and personal issues are carried over to sensitive issues such as ethnicity and religion, which in turn drags larger groups into engaging in prolonged conflict [4], [6], [10].

In Palu, the trigger for the initial conflict was disputes between young people. This dispute then developed into an interfaith issue which later sparked a much larger communal conflict and later became known as the Poso conflict. According to study of Indonesia's National Violence Monitoring System (NVMS), this conflict caused 517 people died, 579 injured, and 6,004 buildings were damaged [6].

Thus, the thin capital of social trust has triggered mutual suspicion that facilitates conflict [11]. But at the same time, social trust has also been eroded by the conflict. Even now, when the conflict has been successfully muted, matters related to social trust are still interesting to study further considering these factors become important capital for maintaining harmonization and positive dynamics in relations between groups in society. This study aims to map social trust of post conflict society, particularly in Poso Regency, after almost two decades after the Malino peace agreement.

\section{Research Method}

There are dozens of groups involving thousands of people involved in this prolonged conflict. As a result of this conflict seen until now, such as the formation of settlement patterns between segregated social groups, spread in groups to certain areas in Poso District. 
This study was conducted in Poso Regency, Central Sulawesi Province, because it is a post-conflict area and is prone to have re-emergence of conflict. Poso Regency consists of 18 sub-districts with an area of $8,712.25 \mathrm{~km}^{2}$ and has a population of 225,379 inhabitants [12]. The research was conducted in August 2017. This study employs quantitative method by distributing questionnaires in sub-districts in Poso randomly. There were 450 questionnaires were distributed and 373 respondents or 83 percent were returned. The quantitative approach was chosen to analyze the questionnaire data, especially by utilizing descriptive statistical analysis in the form of frequency tables and averages to see the distribution and tendency of the phenomenon under study. To get a more adequate explanation of a particular phenomenon or case, a series of in-depth interviews and focus group discussions (FGD) were also conducted with a number of community leaders, young people, conflict actors, and local security forces.

\section{Result and Discussion}

\subsection{Poso Society's Social Trust}

The measurement of the level of social trust is based on answers to questions raised about perceptions of various social groups that exist around young respondents (high school students). These groups have different social distances so as to allow variations in the level of social trust. The whole groups related to social beliefs that were asked to respondents in order are family, neighbors, people of my ethnicity, non-ethnic people, other people of the same religion, others not of a religion, foreigners and how the beliefs of people around the respondents themselves.

Based on trust in various social groups in helping to solve problems faced by respondents, the family is the one who has the greatest level of trust. This was indicated by the presence of 91.2 percent of respondents who said they believed and even trusted their family. Even the percentage with a very high level of "trust" or "very trust" also occupies the largest and most prominent percentage which reaches 49.6 percent.

Table 1. Trust in family in helping to solve problems faced by respondents

\begin{tabular}{crr}
\hline & Frequency & Percent \\
\hline Not trust at all & 3 & .8 \\
Not trust & 30 & 8.0 \\
Trust & 155 & 41.6 \\
High trust & 185 & 49.6 \\
Total & 373 & 100.0 \\
\hline Source: Survey Data, 2017 & &
\end{tabular}

The high level of trust in the family can be understood considering that most of the young age groups that are respondents still live with the family, and even with the extended family environment. That way, the family gives the first response when someone faces problems in 
daily life. Even though the level of trust in the family has the highest percentage, it is still interesting to look at 8.8 percent who say "don't believe" and "don't believe very much". For the measurement of the level of trust in the most basic social groups such as family, this percentage cannot be underestimated given its function as a very basic glue for society.

Apart from family, the level of trust is low towards other social groups. This can be seen in the large percentage of those who claim to "not believe" or even "very distrust" of various social groups outside their own family. Even to their own neighbors, those who "believed" and "strongly believed" were only 22.8 percent, the rest "did not believe" 63.0 percent and "strongly did not believe" as much as 14.2 percent. These figures indicate a very low level of trust in neighbors.

Table 2. Trust in neighbors in helping to solve problems faced by respondents

\begin{tabular}{rrr}
\hline & Frequency & Percent \\
\hline Not trust at all & 53 & 14.2 \\
Not trust & 235 & 63.0 \\
Trust & 74 & 19.8 \\
High trust & 11 & 2.9 \\
Total & 373 & 100.0 \\
\hline
\end{tabular}

Source: Survey Data, 2017

It has been understood that Indonesian people are characterized by being very close and close to neighbors, especially in rural areas and small towns like Poso. That causes them to usually have high mutual trust and be a capital in fostering daily life, regardless of ethnicity, religion, or race. 2014 Social and economic survey data, for example, shows that the average household in Indonesia who believes/strongly believes in leaving their house with neighbors when no family member is at home is 82.28 percent. While those who believe entrust children (aged 1-12 years) when none of the adult family members are at home by 64.36 percent. This is also shown by the average level of trust in neighbors in the province of Central Sulawesi where Poso District is located which is not much different nationally, 83.94 percent for home care and $64.11 \%$ for child care [12]. Meanwhile, even though it was asked differently, the figure of 22.8 percent of respondent of this study shows a very low percentage of trust compared to other regions in Indonesia.

The pattern of answers is almost the same if trust is asked to people of my own ethnicity, even with a slightly higher percentage of confidence level, as shown in data table 3.

Table 3. Trust in people in their tribe in helping to solve problems faced by respondents

\begin{tabular}{crr}
\hline & Frequency & Percent \\
\hline Not trust at all & 29 & 7.8 \\
Not trust & 244 & 65.4 \\
Trust & 94 & 25.2 \\
\hline
\end{tabular}




\begin{tabular}{rrr}
\hline High trust & 6 & 1.6 \\
Total & 373 & 100.0 \\
\hline
\end{tabular}

Source: Survey Data, 2017

The percentage of the level of confidence returned slightly decreased if the respondents were asked their confidence in other people who are not of their own ethnicity in helping to solve the problems they are facing. There are $79.4 \%$ of respondents who answered "don't believe" and "strongly don't believe". However, a fairly high percentage compared to belief in previous social groups is classified as "very distrust" which reached $18.8 \%$. This shows a tendency for a lower level of trust in ethnic differences compared to family or neighbor differences.

Table 4. Trust in others who are not of your own ethnicity in helping to solve problems faced by respondents

\begin{tabular}{crr}
\hline & Frequency & Percent \\
\hline Not trust at all & 70 & 18.8 \\
Not trust & 226 & 60.6 \\
Trust & 74 & 19.8 \\
High trust & 3 & .8 \\
Total & 373 & 100.0 \\
\hline
\end{tabular}

Source: Survey Data, 2017

In contrast to family and most of neighbors who are still known to be close by respondents, ethnic differences usually do not always indicate a high intensity of interaction in daily life. In addition, in a very heterogeneous society, ethnic differences are also not uncommon to be a marker of other differences such as the religion adopted or other habits.

In this study, religious similarities or differences seem to be the main basis in social belief after family. As a young group who live in an environment that has experienced religious conflict, this situation is certainly not surprising. This is indicated by the percentage that reaches 42.2 percent who "believe" and 6.7 percent who "strongly trust" other people of the same religion in helping to solve the problems faced by respondents. When combined between the attitude of "believe" and "very believe", then nothing reaches above 40 percent other than the family and the similarity of religion.

Table 5. Trust in others of the same religion in helping to solve problems faced by respondents

\begin{tabular}{crr}
\hline & Frequency & Percent \\
\hline Not trust at all & 17 & 4.6 \\
Not trust & 181 & 48.6 \\
Trust & 150 & 40.2 \\
\hline
\end{tabular}




\begin{tabular}{rrr}
\hline High trust & 25 & 6.7 \\
Total & 373 & 100.0 \\
\hline
\end{tabular}

Source: Survey Data, 2017

Although a little lower level of trust in those who are not religious, but does not have much difference with the pattern of answers found in the belief in neighboring groups and tribes. The pattern of answers to different religious groups seems to be inconsistent with the pattern of previous answers related to religious similarity. The presumption that a relatively high belief in a religious group will cause a reverse response pattern - that is, relatively low - in groups of different religions is not proven prominently. It seems that for young people in Poso a good impression on a religious group is more prominent than a bad impression on a nonreligious group. In other words, the prominence of belief in a religious group does not always mean that it will reduce the belief in a non-religious group

Table 6. Trust in others who are not of religion in helping to solve problems faced by respondents

\begin{tabular}{rrr}
\hline & Frequency & Percent \\
\hline Not trust at all & 62 & 16.6 \\
Not trust & 232 & 62.2 \\
Trust & 76 & 20.4 \\
High trust & 3 & .8 \\
Total & 373 & 100.0 \\
\hline
\end{tabular}

Source: Survey Data, 2017

The lowest and most different level of trust compared to other social groups is happening to foreigners. When combined with answers that say "don't believe" and "don't believe very much", then there are 94.1 percent of these young people who have answers like that. In fact, there were 46.1 percent who said "strongly do not believe" and absolutely no one said "strongly believe" to strangers.

Table 7. Trust in foreigners in helping to solve problems faced by respondents

\begin{tabular}{rrr}
\hline & Frequency & Percent \\
\hline Not trust at all & 172 & 46.1 \\
Not trust & 179 & 48.0 \\
Trust & 22 & 5.9 \\
High trust & 0 & 0.0 \\
Total & 373 & 100.0 \\
\hline
\end{tabular}

Source: Survey Data, 2017 
There is no information relating to the explanation of the low level of trust in foreigners who are very prominent compared to other groups. However, this is allegedly due to the lack of association between these young age groups with them, aside from the quite dominant narrative in society that often links social conflict with outside interference, including foreigners.

If what has been revealed previously is related to young people's trust in other social groups, then the following wants to know how much they believe that people around them also believe in them. Respondents were asked how much trust they would be approached to ask for help if the people around them needed it. If the answers "believe" and "really believe" are combined then the percentage is 53.9 percent. Most respondents were between "believe" and "distrust" of the possibility of other people asking for help, amounting to 85.8 percent.

Table 8. Trust in coming to the respondent to ask for help if the people around him have a problem

\begin{tabular}{crr}
\hline & Frequency & Percent \\
\hline Not trust at all & 20 & 5.4 \\
Not trust & 152 & 40.8 \\
Trust & 168 & 45.0 \\
High trust & 33 & 8.8 \\
Total & 373 & 100.0 \\
\hline Source: Survey Data, 2017 & &
\end{tabular}

The tendency of respondent's answers that the percentage is large and almost balanced between those who answer "believe" and "don't believe" indicates not only the level of confidence in him, but also related to the way young people perceive their role in society that is not yet fully established. On the other hand, the public is also perceived as not fully expecting too large a social role for young people outside of their efforts to prepare themselves for the future.

If the eight forms of trust as stated earlier are combined into one with averaging values, then the results obtained as in Figure 1 show the percentage of respondents according to general level of trust. The picture shows that in general the level of trust among young people in their social environment tends to be low, where there are 70 percent who "don't believe" and there are even 3 percent who "strongly don't believe". The rest are those who "believe" by 26 percent and only 1 percent who have a very high level of trust and answer "very believe".

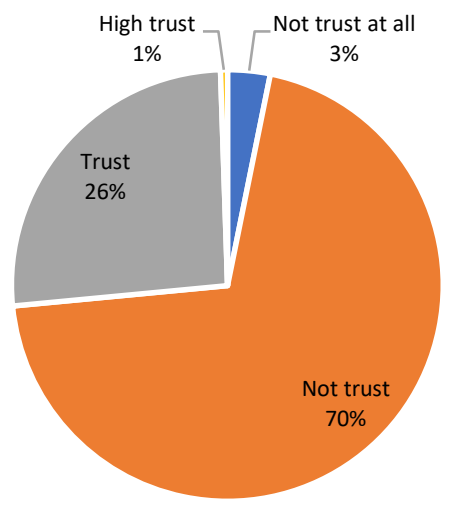


Fig. 1. Percentage of respondents according to general level of trust $(\mathrm{N}=373)$

The level of trust among young people towards their social environment in general is relatively low indicating that they have not fully recovered due to the conflict. A more latent attitude of mistrust appears to be much slower to recover than openly stopping conflict.

\subsection{Coordination in Building Trust}

After massive violent conflict in Poso, there were still occasional small explosions of conflicts that occur in various places. The conflict seems to have the potential to develop into a large, especially because of inadequate trust capital that was eroded during a prolonged open conflict. The erosion of trust due to social conflict can be seen from the results of the research stated earlier. This low level of trust is especially common among people of different religions and towards foreigners. Recognizing these conditions, the community together with the government seeks to build trust through efforts across social groups, especially across religions.

The result of cross-group efforts in building trust is intensifying communication and coordination through institutionalized institutions. One problem related to efforts to build this institution is also related to the issue of trust among the figures who formed it. If these figures can maintain the neutrality and trust of the community, then the institution he built can also function because he has the support and trust of the community, as a key informant who is a religious leader said:

Community leaders have a very important role, especially those who are consistent between words and deeds. If it does not behave like that it will be ignored by the community. Although he is a person who has a position. So, this is a matter of trust. And authority grows from trust. (Interview, 15 August 2017)

This study identified institutions that were involved in reducing the possibility of conflict, namely the Interfaith Communication Forum (FKUB) and the Community Early Awareness Forum (FKDM). Various parties from the community, religious leaders, the police, and also the regional government through the Poso Regency National Unity and Politics Agency were involved in both institutions. Although some key informants consider the two institutions seem very slow to prevent conflicts in some cases, but the presence of these institutions shows the awareness of the need to establish communication, because without this will provide opportunities for widespread distrust and mutual suspicion that can trigger conflict recurrence.

\section{Conclusion}

This research shows that the level of community trust - in this case young people / students - towards other parties in areas that have experienced conflict is quite low. Even though there 
are only $3.2 \%$ who are in the "very distrust" group, but the majority of them $(70.2 \%)$ are at the level of "no confidence". Such low levels of trust in others only experience exceptions to their families.

The amount of mistrust towards other parties looks good to those of their ethnicity, especially if they are of different ethnicity, religion, and to a foreign party. This shows that post-conflict social recovery efforts that have so far not been fully successful in restoring trust among community members. However, if this is not handled properly, it can develop towards people whose members are increasingly distrustful and not trusting each other or low trust communities. As net result, they will be difficult to work together and increasingly vulnerable to conflict.

To bridge and assist in the restoration of post-conflict trust, awareness has emerged among community and religious leaders of the importance of open communication and ongoing coordination. One manifestation of this awareness is the formation of institutions or forums across social/religious groups. This model requires continuous improvement in order to be able to prevent conflict on an ongoing basis

\section{References}

[1] Nasikun, N.: Sistem Sosial Indonesia. Jakarta: Rajawali Pers (1985)

[2] Dahrendof, R.: Class and Class Conflict in Industrial Society. California: Stanford University Press (1959)

[3] Prasetyantoko, A.: Paradoks Ekonomi dan Agenda Kesejahteraan Sosial, in Pembangunan Inklusif, Propspek dan Tantangan Indonesia, Jakarta: LP3ES, pp. 21$54(2012)$

[4] Barron, P, Kaiser, K and Pradhan, M.: Understanding Variations in Local Conflict: Evidence and Implications from Indonesia, World Dev., Vol. 37, no. 3, pp. 698-713, (2009)

[5] Yani, A. A.: The Local Government and Violent Conflicts Mitigation in the Post Conflict Areas in Indonesia ; a Case Study in the Regency of North Luwu," Utrecht University.

[6] Varshney, A. Panggabean, R and Tadjoeddin, M. Z.: Patterns of Collective Violence in Indonesia (1990-2003) (2004)

[7] Yani, A. A.: Ensuring Peace Environment in Post Conflict Society Through Institutional Engineering; An Indonesian Case Study,Vol. 1, no. 1, pp. 13-34, (2017)

[8] Barron, P. Jaffrey, S. Palmer, B. and Varshney, A.: Understanding Violent Conflict in Indonesia. A Mized Methods Approach (2009)

[9] Delhey, J and Newton, K.: Who trusts?: The origins of social trust in seven societies, Eur. Soc., Vol. 5, no. 2, pp. 93-137 (2003)

[10] Aragon, L. V.: "Communal Violence in Poso, Central Sulawesi: Where People Eat Fish and Fish Eat People," Indonesia, Vol. 72, no. 72, p. 45 (2001)

[11] Cox, M.: Social Capital and Peace-Building. London: Routledge (2009)

[12] BPS Poso, Kabupaten Poso Dalam Angka 2017.: Poso: Badan Pusat Statistik Poso (2017) 